\title{
The 'Road' Less Travelled: Commemorating those who lie in Sea Graves
}

\author{
By Patrick O'Leary * \\ Caroline Winter
}

\begin{abstract}
Battlefield tourism is an increasing global phenomenon, often associated with a 'memory boom' and a desire for families to trace their own place in national history. It has also been argued, that travel to sites of conflict is one of the ways in which social memory can be created and perpetuated. In Australia for example, travel to the Gallipoli battlefield of the First World War has become a 'rite of passage' for younger generations. In this paper, we explore the notion that social memory of Australians at war is associated with a limited number of sites, particularly Gallipoli, Villers-Bretonneux and the Kokoda Track. Part of the reason for this may be that physical access to these sites is relatively easy, given the vast improvements in international travel options, as well as a plethora of media coverage. There are many other sites that equally deserve to hold special significance for Australians but which do not attract the same attention, particularly because they are far harder to visit and even harder to find. Naval 'grave' sites are a case in point. This paper traces a family visit to the site of the 1942 sinking of the HMAS Perth and the USS Houston off north-west Java to commemorate the 70th anniversary of 'The Battle of the Sunda Strait'. Naval war graves present special demands on those few intrepid pilgrims who choose 'the road less travelled', none more than the alien environment, the difficulties in identifying the site itself and the effects of the lack of social memory about such sites. Keywords: markers; naval heritage; pilgrimage; memory; HMAS Perth; USS Houston; Second World War
\end{abstract}

\section{Introduction}

This paper is not a work of history, although it deals with some historical events. While the historical events in question are integral to this paper, it is an understanding of the relationship between a series of historical events and a recent tourism event which is the main purpose. The historical events in question concern the loss of the HMAS Perth and the USS Houston in the Sunda Strait, off north-west Java, on 1 March 1942. The recent tourism event

${ }^{*}$ Lecturer, Federation University Australia.

${ }^{\dagger}$ Senior Lecturer, Federation University Australia. 
was the visit to the 'site' by some family members of the crew of the HMAS Perth, to commemorate the $70^{\text {th }}$ anniversary of the Battle of the Sunda Strait, on 31 March 2012.

Walter (2009) conceptualises the memory of war as a temporal proximity across three generations, with the first-generation relating to the memory of events, places and people that were personally experienced, and secondgeneration memories are those handed down by parents to their children. By the third generation and later the past enters our consciousness in different ways, and 'it is not possible to put a number on how many years or generations must pass before an event passes into history and loses its emotional and possibly traumatic hold on visitors' (Walter, 2009: 47). In this paper the voice of one of the authors is used to describe the pilgrimage undertaken as part of a family group to the site of HMAS Perth.

As we stood on the decks of two small power-boats bobbing like corks on the rolling ocean swell out in the Java Sea, some five-kilometres off the northwest tip of Java, Indonesia, I could scarcely comprehend the significance of what was taking place. On the boat with me were my family, the descendants of a brave 35-year old father of five, for whom we had come thousands of kilometres to pay our respects.

On these two boats were 13 pilgrims, from various parts of Australia, commemorating the 70th anniversary of the sinking of the HMAS Perth and the USS Houston early on the morning of 1 March 1942, in what became known as 'the Battle of the Sunda Strait'. This was the first opportunity for family members to attend the sea grave of their lost kin.

Naval war graves present special demands on those few intrepid pilgrims who choose 'the road less travelled', none more so than the alien environment, the difficulties in identifying the site itself and the effects of the lack of social memory about such sites.

\section{Literature Review}

\section{Family and National History}

During the First World War, the acknowledgement given to soldiers in war and their burial in individual graves meant that the memory and history of family and nations became closely linked (Slade, 2003; Winter, 1995, 2006; Ziino, 2010). Grant (2006: 20) argues that these traditions were originally formulated in the American Civil War, and given expression in the commemorative landscape at Gettysburg: individuals distinguished by state, a separate section for 'unknown' no distinction of class or status in the grave markers and burying soldiers in the field where they fell. Unlike the practices of a century before, family now had a specific place to visit that was more personal than simply a general battlefield. In addition to the monumental public memorials, there are also many smaller private memorials and practices, and a great deal of 'memory work' is carried out by small committed groups of people, especially families (Winter, 1995, 2006). 
Travel associated with war has been conceptualised in a number of ways. After the First World War the form of travel was conceptualised and actualised as secular 'pilgrimage' and until recently, the journeys of battlefield pilgrims and tourists were valued and conceptualised differently. Pilgrims were portrayed as those who had the single purpose of visiting a particular grave or memorial of family or colleagues, and they regarded the battlefields and graves as sacred while tourists were thought to focus on education and leisure activity (Baldwin and Sharpley 2009; Connelly, 2009; Iles, 2008; Mosse, 1990; Walter, 1993; Winter, 1995, 2006; Lloyd, 1998). The lines of distinction between tourists and pilgrims have substantially blurred with some views suggesting that definitions of pilgrims and tourists exist along a continuum, and others arguing that situational and experiential factors determine a visitor's perspectives (Bremer, 2006; Digance, 2003).

\section{The Memory Boom and Travel for Family History}

Associated with pilgrimage is the increasing global phenomenon, known as the 'memory boom' which involves the desire of families to trace their own place in national history. Tourism plays a critical role in much family history, by facilitating physical and information access. 'Legacy tourists are those that travel to engage in genealogical endeavours, to search for information on or to simply feel connected to ancestors and ancestral roots' (McCain \& Ray, 2003: 713), where tourists were concerned to find 'places where family is from' (McCain \& Ray, 2003: 716). Similarly, Santos and Yan (2010: 56) describe a niche of Genealogical tourists who are 'amateur genealogists who travel to destinations that make available resources that support family history research'. Both types of tourists were more highly committed than other tourists in their motivation and tended to place less emphasis on other leisure pursuits.

\section{Access}

Naval war graves present special demands on those few intrepid pilgrims who choose 'the road less travelled', none more than the alien environment, the difficulties in identifying the site itself and the effects of the lack of social memory about such sites. This access has significant implications, because, as Foote and Azaryahu, (2007: 126) explain, 'memory pertains to the actualisation of the past in some form of contemporary experience'. Dunkley et al. (2010) found there is a deep significance of the actual battle sites to the experience of the participants.

There are many sites that equally deserve to hold special significance for Australians but which do not attract the same attention, particularly because they are far harder to visit and even harder to find. Naval 'grave' sites are a case in point. It is perhaps an irony that the tourism industry, usually associated with pleasure and fun, is most appropriately geared to provide access to these challenging sites. 


\section{Tourist Markers and the Importance of Place}

The importance of site 'marking' is illustrated in this paper through an examination of a naval battle site: 'The Battle of the Sunda Strait', involving the HMAS Perth and USS Houston in Indonesia. MacCannell (1989) showed the importance of 'markers' at a site, which allow tourists to interpret it. Using MacCannell's theory of 'site sacralisation' tourism researchers have shown how a complex marking process involving naming, framing, elevation, enshrinement, and mechanical reproduction can operate to create a battle site that attracts many visitors. Seaton (1999) for example researched Waterloo and Slade (2003) Gallipoli.

The notion of a tourist 'marker' applies the notion of a 'sign' to a tourism context, whereby a marker (the signifier) provides information about a sight (the signified). To be transmitted, these meanings depend upon the existence of prior codes of signification in the intended audience. Battle sites may be marked by the presence of military equipment, but in many cases, they are devoid of any evidence at all and thus need to be marked in some way for visitors. MacCannell (1989) also uses battlefields as an example of markersight obliteration, whereby for any number of reasons, information about the sight is lost, or where the link between the marker and the site is lost.

It is much easier to mark a land-based battlefield, rather than one in the air or at sea, and most countries have war memorials comprising large stone monuments in various forms, which act as signs for national battles. The war dead of a nation are often regarded as sacred and as heroes and thus their burial places have great importance for their families and for the nation. Again, on land, they are relatively easy to mark. Laqueur (1994) observes that 'bodies, of course, being in the ground, are hidden and cannot be their own memorials, but markers of their skeletal uniformity serve the purpose' (Laqueur, 1994: 161). Even when bodies are missing, memorials can list their names - again, this often occurs on large stone monuments and war memorials. But seawater places, the sites of battles and the graves of men are much more difficult to mark. The journey described here clearly illustrates this notion of what MacCannell (1989) referred to as marker-sight obliteration.

\section{The 'Life and Times' of the HMAS Perth}

The sinking of the HMAS Perth stood out as a significant loss, not just for the families of the men who died that day or during their captivity by the Japanese war-machine, but also for the Royal Australian Navy during the Second World War and the Australian community. The HMAS Perth was one of three Royal Australian Navy Modified Leander-class Light Cruisers (Pfennigwerth, 2007), along with the more infamous HMAS Sydney, sunk in controversial circumstances with all 645 crew lost in November 1941, and the HMAS Hobart, which survived Second World War, although not without seeing significant action and sustaining major damage in 1943 (Charlton, 2011; Pfennigwerth, 2007; Roberts, n.d.). The British Royal Navy had built the three 
vessels in peace-time, the Sydney in 1934 and the Perth and Hobart in 1936, and the Royal Australian Navy had purchased them in 1934 and 1939 respectively.

The Perth saw action in the Caribbean and the Atlantic even before arriving in Australia in March 1940. Subsequently the Perth saw action, first as a convoy escort and on coastal patrols in the Indian Ocean, before being sent to the Mediterranean Theatre in November 1940 to relieve the Sydney. The Perth served with distinction in the Mediterranean Theatre, patrolling the Aegean and supporting convoys to Malta, patrolling around Greece and Crete and supporting the Allied reinforcement of Greece, playing a major role in the Battle of Cape Matapan and the evacuation of Greece. In April and May 1941, Perth was involved in the Battle of Crete, where it sustained some damage, as well as the loss of four of the ship's crew and nine of the soldiers being evacuated from the Island. The Perth also played a major role in the Allied action against Vichy French forces in Syria in June and July 1941, before being relieved by the Hobart, arriving back in Australian waters for repairs, an upgrade to its anti-aircraft armaments and a general refit in August 1941. The ship resumed escort and coastal patrol duties in the Indian Ocean after the refit (Charlton, 2011; Pfennigwerth, 2007; Roberts, n.d.).

On 14 February 1942, the Perth sailed for the Dutch East Indies (Indonesia), initially to escort oil tankers, but eventually to join the AmericanBritish-Dutch-Australian (ABDA) fleet. Within 15 days, the Perth would be 'afast on the ocean bed', along with virtually the entire ABDA fleet. The Perth met the other four cruisers and nine destroyers on 25 February 1942 at Surabaya, now just four-and-a-half days from sinking. The ABDA fleet sailed to meet a Japanese convoy of eight cruisers, 12 destroyers and 30 troop transport ships, engaging this invasion force on 27 February 1942 in what became known as the 'Battle of the Java Sea'. By the time the Perth and the USS Houston broke off their engagement late on 27 February, the other three cruisers, the Dutch HNLMS De Ruyter and Java were 'afast on the ocean bed' and the HMS Exeter was severely damaged and out of action, along with several ABDA fleet destroyers (Charlton, 2011; Pfennigwerth, 2007; Roberts, n.d.).

The Perth, largely undamaged although very low on fuel and ammunition, and the Houston, carrying significant damage from the 'Battle of the Java Sea', arrived in Tanjong Priok, the port district of Batavia (now Jakarta) on 28 February 1942. Within hours, without being able to fully refuel or rearm, the Perth, in the lead, and the Houston sailed for the south-Java port of Tjilatjap (now Chilachap) via the Sunda Strait. Out of date Allied intelligence suggested the route was free of enemy vessels, however a large Japanese invasion-force had assembled north of Bantam Bay. Within five-and-a-half hours both cruisers would be 'afast on the ocean bed', the Perth at 00:25 and the Houston at 00:45 on 1 March 1942 (Charlton, 2011; Pfennigwerth, 2007).

Of the Perth's original crew of 646, 314 were killed in the action; 332 survived the sinking, although four died after reaching shore, while the remaining 328 were captured as prisoners of war. One hundred and six died 
during their internment, including 38 killed by Allied attacks on Japanese 'hell ships'. The remaining 218 were repatriated after the war. Of the Houston's original crew of 1061, 688 were killed in the action; 373 survived the sinking, although five died or were killed by the Japanese after reaching shore, while the remaining 368, including 24 of the 74-man US Marine Corp detachment, were captured as prisoners of war. Seventy-five died during their internment, including three killed by Allied attacks on Japanese 'hell ships'. The remaining 288 were repatriated after the war (Pfennigwerth, 2007).

The Perth's wartime service was later recognised with the following battle honours: 'Atlantic 1939'; 'Malta Convoys 1941'; 'Matapan 1941'; 'Greece 1941'; 'Crete 1941'; 'Mediterranean 1941'; 'Pacific 1941-42'; and 'Sunda Strait 1942' (Charlton, 2011; Pfennigwerth, 2007).

\section{The $70^{\text {th }}$ Anniversary Odyssey to the Sunda Strait}

One of the authors bears the name of a Stoker who was killed by the first torpedo strike, on the forward engine room.

The recent tourism event grew out of discussions at a family birthday gathering in April 2011, initiated by one of the gifts, a large, framed reproduction poster of an 'oil-on-canvas' of the HMAS Perth under fire during the 'Battle of the Sunda Strait'. While we spoke with a great deal of enthusiasm about the notion of commemorating the $70^{\text {th }}$ anniversary of the sinking of the Perth at the actual site, we really had no idea at that point what it would take to finally join the great cloud of 'intrepid' souls undertaking war tourism.

Within weeks of this discussion the family began the journey of discovery of how difficult this proposed trip would prove to be. By the end of 2011 we had a tour company booked and where working with them to find and book hotel accommodation. It was relatively easy to find a hotel in Jakarta, but Merak, the town from where we would embark on our boat ride some five kilometres out to the wrecks of the Perth and the Houston, was far more challenging. The north-west and Sunda Strait coastal areas of Java do not attract many western tourists, and modest accommodation was virtually nonexistent. It should be noted that the party for the trip had grown from five-to 13, which of course created another level of complexity.

Once the research and initial bookings were completed we proceeded to book flights and notify the Australian embassy in Jakarta. At this point the original travel plans again took on another layer of complexity due to two factors. First, the cost of the airfares to Jakarta could be halved if this trip was included as a stop-over on flights to Bali. Consequently, we now had to plan a separate trip to Bali, and on the advice of our tour guides for just a few dollars more we could extend our stay in west Java by an extra two days and visit Anak Krakatau (the active volcanic island that emerged out of the sea where Krakatoa once stood, many years after Krakatoa had erupted in 1883). Second, the Australian embassy staff in Jakarta invited our party to hold a $70^{\text {th }}$ anniversary ceremony at the only war grave marker to the Perth and the Houston in the area, on the grounds of the embassy. What had started out as a 
small family trip to the wreck of the Perth had now become a major journey of discovery.

The trip itself was far more challenging than family members had anticipated - it was indeed a pilgrimage in the sense of being a long and arduous journey. The participants left from various points in southern Australia, early on 29 March 2012, arriving in Jakarta during the afternoon 'rush-hour' on that same day. While the trip from the airport to the hotel was extraordinary, it was what any other visitor to a large Asian city would experience. After a very comfortable stay in a large international hotel, the trip to the Australian embassy proved difficult, and what should have been a 45minute trip became a two-and-a-half hour ordeal through grid-locked traffic, diverted around protestors.

After the very moving ceremony at the embassy the party embarked on what to their eyes was another challenging trip. The tour guides, who would take the party from the hotel in Jakarta, to the Australian embassy, to Merak and the wreck sites, to Chirita and Anak Krakatau, and finally back to Jakarta along the remote 'highway' through the mountains of central-west Java, were rightly proud of their own history and wanted to show off two jewels in Java's historical crown. This meant two significant detours from the major highway system, along very rough roads, through poverty-stricken towns and villages to a ruined palace and a Chinese temple. The group left Australia on Thursday, 29 March 2012 and arrived in Merak as the sun was setting over Sumatra, directly across the Sunda Strait from the hotel on Friday, 30 March. While this was a day-and-a-half of hard traveling, Merak was like another world: the once beautiful ancient settlement of Merak had been completely destroyed by Krakatoa's 45-metre high Tsunami in 1883. What 'grew' back was an outpost which became the ferry port for one side of the Sunda Strait and the site of a coal and gas fired power station, because of its proximity to the ocean. It was, however, the group's point of departure the next morning on our original destination, the wreck sites of the Perth and the Houston.

While the trip thus far was an adventure, the journey to the Perth was an altogether different experience. By definition, the Battle of the Sunda Strait should have occurred in the Sunda Strait, however, the boats headed to a GPS point some five kilometres north of Merak, out in to the Java Sea. It also was somewhat of a mystery, as the travellers were entirely at the mercy of the tour guides leading the way. At 36-metres, the Perth is completely hidden by the rolling swells that race in from the Java Sea through the Sunda Strait and out into the waists of the Indian Ocean to Africa. At a predetermined point on what seemed like an endless ocean, the crew member holding the GPS device called a halt to the trip. None on board the two power boats knew if this was the precise position of the Perth, as it rested 'afast on the ocean bed', however, a subsequent event raised grave doubts among many of the well-read pilgrims. Once the ceremony was over, the guides were to take the party to the wreck of the Houston, to lay a wreath for her brave crew. The maps and other research indicated that Perth lay in 36 metres of water, while the Houston lay some distance south-east of the Perth, much closer to Java in 28 metres of water. The 
guides, however, took the group further out to the north-west, where the swell was much bigger.

To this day, we don't know if we were anywhere near the Perth when we commemorated its sinking on 31 March 2012.As witnessed during the ceremony at the only marker to the Perth and Houston, in the grounds of the Australia embassy in Jakarta, several hundred kilometres east-south-east of the wreck, the grief, despite 70 years of life, love, family and new memories, was still too fresh for the sons of the departed, who, perhaps, lay beneath our feet, 'afast on the ocean bed'. This raises an important point. We had planned and made this difficult journey for one purpose, to remember and respect the brave men who served and died on these two ships, in a futile attempt to halt or postpone the Japanese invasion of the Dutch East Indies (Indonesia). When all was said and done, this journey meant more to us than whether we were right over the Perth (we probably drifted several hundred metres during the ceremony anyway). In the end, the journey to the Perth was more about the pilgrimage than the destination. Perhaps, more than anything else, this sets most naval grave site tourism apart from land based sites such as in France and Turkey. The journey means more, precisely because it is so difficult and so alien.

\section{Conclusion}

The journey described here illustrates some of the traditional aspects of pilgrimage: the focus upon visiting a specific sacred site, the community of interest and the arduous and uncertain nature of the travel. While the notion of pilgrimage may be less clear in relation to battles of several generations before, it clearly remains an important concept for at least some visitors to sites of recent conflict. But this was also a trip in a touristic sense, in that the tourism industry facilitated the journey through its provision of accommodation, guides and transport.

As others have noted (Dunkley et al, 2010) the specific sites of battle events hold great importance to people, supporting the notion of the geographic location of memory (Foote \& Azaryahu, 2007). Because of their distance from overseas battlefields, Australians have been forced to commemorate war in the absence of the deceased, but this is on the understanding that graves do exist (Ziino, 2007). For sea graves in isolated locations, such as the HMAS Perth and USS Houston which are not marked, at least not above the waves, the perpetuation of their memory is very challenging. Laying the wreath provides for a few minutes or perhaps a few hours, a marker for the water graves and links the living family members with their deceased kin below.

As Winter (1995) observed, memory is usually maintained by small groups such as families, and in this case, the group was willing to undertake the very difficult journey if only for a short visit. The journey reflects and supports the work of Santos and Yan (2010) and McCain and Ray (2003) who conceptualised legacy and genealogical tourism, and described the intensity and devotion that such tourists make towards their tasks. 
Visits to sea graves have been given little attention in the literature, perhaps for reasons of the difficult access, as has been shown in this paper. While families hold the memory of these men, it is timely that the broader society begins to acknowledge the actions of these brave men who by the inconvenience of their last battle site have not been given the acknowledgement accorded to those in more accessible graves.

\section{References}

Dunkley, R., N. Morgan \& S. Westwood (2011) 'Visiting the trenches: Exploring meanings and motivations in battlefield tourism.' Tourism Management 32(4): 860-868.

Charlton, M. (2011). Cruiser: The life and loss of the HMAS Perth and her crew. Melbourne: William Heinemann Australia

Foote, K. \& M. Azaryahu (2007). Toward geography of memory: Geographical dimensions of public memory and commemoration. Journal of Political and Military Sociology 35(1): 125-144.

Gatewood, J. \& C. Cameron (2004) 'Battlefield pilgrims at Gettysburg National Military Park.' Ethnology 43: 193-216.

Inglis, K. (2005). Sacred Places: War Memorials in the Australian Landscape. Melbourne: The Miegunyah Press.

MacCannell, D. (1989). The Tourist. New York: Schocken.

McCain, G. \& N. Ray (2003). Legacy tourism: The search for personal meaning in heritage travel. Tourism Management 24: 713-717.

Pfennigwerth, I. (2007). The Australian cruiser Perth 1939-1942. Sydney: Rosenberg.

Poria, Y., A. Reichel \& A. Biran (2006). 'Heritage site perceptions and motivations to visit.' Journal of Travel Research 44: 318-326.

Roberts, R. (n.d.). Age shall not weary them: the story of the H.M.A.S. Perth. Perth: Patersons Printing Press Limited.

Santos, C. \& G. Yan (2010). 'Genealogical tourism: A phenomenological examination.' Journal of Travel Research 49(1): 56-67.

Seaton, A. (2000). 'Another weekend away looking for dead bodies... battlefield tourism on the Somme and in Flanders.' Tourism Recreation Research 25: 63-77.

Shih Shuo, Y., C. Ryan \& G. Liu (2009). 'Taoism, temples and tourists: The case of Mazu pilgrimage tourism.' Tourism Management 30: 581-588.

Slade, P. (2003). 'Gallipoli Thanatourism: The Meaning of ANZAC.' Annals of Tourism Research 30: 779-794.

Turner, J. \& G. Ashworth (1996). Dissonant Heritage: The Management of the Past as a Resource in Conflict. Chichester: John Wiley and Sons.

Turner, V. \& E. Turner (1978). Image and Pilgrimage in Christian Culture. Oxford: Basil Blackwell.

Walter, T. (1993). ,War grave pilgrimage.' In Reader I. \& T. Walter (eds.). Pilgrimage in Popular Culture, 63-89. London: Macmillan.

Walter, T. (1999). On Bereavement: The culture of grief. Buckingham: Open University Press.

Walter, T. (2009). 'Dark tourism: Mediating between the dead and the living.' In R. Sharpley \& P. Stone(eds.). The darker side of travel: The theory and practice of dark tourism. Clevedon: Channel View Publications. 
Winter, J. (1995). Sites of Memory, Sites of Mourning: The Great War in European Cultural History. Cambridge: Cambridge University Press.

Winter, J. (2006). Remembering War: The Great War Between Memory and History in the Twentieth Century. New Haven: Yale University Press.

Ziino, B. (2007). A Distant Grief: Australians, War Graves and the Great War. Crawley, Australia: University of Western Australia Press. 